\title{
Evaluation of the addition of tramadol on lidocaine-induced motor block regression time. Experimental study in rats*
}

\author{
Avaliação da adição do tramadol sobre o tempo de regressão do bloqueio motor induzido pela \\ lidocaína. Estudo experimental em ratos
}

Angela Maria Sousa ${ }^{1}$, Martim M Cutait², Hazem Adel Ashmawi

${ }^{\star}$ Recebido do LIM-08 da Faculdade de Medicina da Universidade de São Paulo. São Paulo, SP.

\section{ABSTRACT}

BACKGROUND AND OBJECTIVES: Tramadol blocks somatosensory potentials in vitro and may be associated to local anesthetics to improve analgesic quality. This study aimed at evaluating whether tramadol changes lidocaine motor block regression in two different concentrations.

METHOD: Male Wistar rats weighing 250 to $300 \mathrm{~g}$ were submitted to sciatic nerve block guided by percutaneous nerve stimulation. Animals were distributed in four groups ( $\mathrm{n}=5$ per group): $2 \%$ lidocaine (GI), $0.5 \%$ lidocaine (GII), 2\% lidocaine/ 1.25 tramadol (GIII), 0.5\% lidocaine/1.25 tramadol (GIV). Partial and total motor block regression times were evaluated.

RESULTS: Al animals had total motor block when awakening from anesthesia, which has totally regressed during the observation period. Total regression time of $2 \%$ lidocaine was $41 \pm 1.71$ minutes, $0.5 \%$ lidocaine was $25.26 \pm 0.83$ minutes, $2 \%$ lidocaine/tramadol was $46.06 \pm 0.88$ minutes and $0.5 \%$ lidocaine/ tramadol was $36.15 \pm 1.18$ minutes. The association of $0.5 \%$ lidocaine and $1.25 \mathrm{mg}$ tramadol was more effective as compared to $0.5 \%$ lidocaine alone. Data are presented in mean \pm mean standard error (mse), considering significant $\mathrm{p}<0.05$ using ANOVA followed by Tukey test.

CONCLUSION: Tramadol has effects similar to local anesthetics and, when used as adjuvant of lidocaine, prolongs motor block duration in rats.

Keywords: Lidocaine, Nervous block, Tramadol.

\footnotetext{
1. Team Leader, Cancer Institute of the State of São Paulo. São Paulo, SP, Brazil. 2. Anesthesiologist, Central Institute, Clinicas Hospital, University of São Paulo. São Paulo, SP, Brazil.

3. Professor, University of São Paulo (USP); Supervisor of the Pain Control Team, Central Institute, Clinicas Hospital, University of São Paulo (USP). São Paulo, SP, Brazil.

Submitted in March 25, 2013

Accepted for publication in June 03, 2013.

Correspondence to:

Angela Maria Sousa, M.D

Av. Dr Eneas de Carvalho Aguiar, 255, $8^{\circ}$ Andar PAMB - Serviço de Anestesia

Cerqueira Cesar

05403-000 São Paulo, SP

E-mail: angela-sousa@uol.com.br
}

\section{RESUMO}

JUSTIFICATIVA E OBJETIVOS: O tramadol bloqueia potenciais somatossensitivos in vitro e pode ser associado a anestésicos locais com o intuito de melhorar a qualidade da analgesia. O objetivo deste estudo foi avaliar se o tramadol altera o tempo de regressão do bloqueio motor da lidocaína em duas diferentes concentraçóes.

MÉTODO: Ratos machos da linhagem Wistar, pesando de 250 a $300 \mathrm{~g}$, foram submetidos a bloqueio de nervo ciático guiado por neuroestimulação percutânea. Os animais foram distribuídos em quatro grupos ( $\mathrm{n}=5$ por grupo): lidocaína a $2 \%(\mathrm{GI})$, lidocaína a $0,5 \%$ (GII), lidocaína a 2\% / tramadol 1,25 mg (GIII), e lidocaína a $0,5 \%$ / tramadol $1,25 \mathrm{mg}$ (GIV). Foram avaliados tempo de regressão parcial e tempo de regressão completa do bloqueio motor.

RESULTADOS: Todos os animais apresentavam bloqueio motor completo no momento do despertar da anestesia, que regrediu completamente durante o período de observação. $\mathrm{O}$ tempo de regressão completa do efeito da lidocaína a $2 \%$ foi $41 \pm 1,71$ minutos, lidocaína a $0,5 \%$ foi $25,26 \pm 0,83$ minutos, lidocaína a $2 \%$ / tramadol foi $46,06 \pm 0,88$ minutos e lidocaína a $0,5 \%$ / tramadol foi $36,15 \pm 1,18$ minutos. A associação da lidocaína a $0,5 \%$ ao tramadol $1,25 \mathrm{mg}$ foi mais eficaz que lidocaína a $0,5 \%$ isoladamente. Os dados são apresentados como média \pm erro padrão da média (epm). Considerou-se significativo $\mathrm{p}<0,05$ usando a ANOVA seguido do teste de Tukey.

CONCLUSÁO: Tramadol possui efeitos semelhantes a anestésicos locais e, quando usado como adjuvante da lidocaína, prolonga a duração do bloqueio motor em ratos.

Descritores: Bloqueio nervoso, Lidocaína, Tramadol.

\section{INTRODUCTION}

Tramadol (1-RS, 2RS)-2-[(dimethyl-amine)-methyl]-1-(3 methoxyphenyl)-cyclohexanol hydrochloride is a central action drug sold as a racemic mixture of two enantiomers $[(+)$ and (-) tramadol]. The methyl group in the phenolic part of the molecule is responsible for the opioid agonist activity and its affinity for $\mu$ receptors is approximately 6 thousand times lower than morphine, 100 times lower than dextropropoxyphene and 10 times lower than codeine ${ }^{1}$. After systemic administration, tramadol is demethylated by the P450 cytochrome system in o-desmethyl-tramadol (M1), active metabolite with agonist activity in 
$\mu$ receptors 200 times higher than the original molecule ${ }^{2}$. It has pharmacological effect similar to local anesthetics, blocking action potential conduction in isolated nerves ${ }^{3}$. By spinal route, it suppresses spinal cord somatosensory potentials ${ }^{4}$ and after perineural injection it induces total motor block ${ }^{5}$. A previous study has described different motor block intensities by perineural tramadol in sciatic nerve of rats, where motor block induced with $5 \mathrm{mg}$ tramadol was similar to motor block induced with $2 \%$ lidocaine ${ }^{5}$.

This study aimed at evaluating the possibility of tramadol potentiating duration and intensity of motor block induced by $0.5 \%$ and $2 \%$ perineural percutaneous lidocaine in the sciatic nerve of rats. Parameter was motor block regression time.

\section{METHOD}

Twenty male Wistar rats weighing 250 to 300 g were placed in pairs in cages with 12-hour light-dark cycles. Water and food were supplied ad libitum. Animals were supplied by the Central Vivarium of the School of Medicine, University of São Paulo (FMUSP) and experiments were carried out in FMUSP's LIM-08, after adaptation to the study environment for 30 minutes.

Anesthetic technique: animals were placed in a closed chamber where $4 \%$ isoflurane in oxygen was supplied by gauged vaporizer for anesthetic induction - anesthesia was maintained with $1 \%$ isoflurane via facial mask to allow sciatic nerve block.

Sciatic nerve block: after being anesthetized, right femur greater trochanter was located by palpation and a $2.5 \mathrm{~cm}$ needle without bevel (BBraun, Germany) connected to a Stimuplex nerve stimulator (BBraun, Brazil) to locate the sciatic nerve. The needle was introduced at $1 \mathrm{~mm}$ from right femoral shaft, in the notch located between greater trochanter and ischial tuberosity and was then directed to the ischium. A ground electrode was fixed to the right ear and the needle was connected to an electric cable which supplied initial current with $0.6 \mathrm{~mA}$ intensity able to promote right thigh muscle contraction, which was progressively increased the greater the proximity to the sciatic nerve. Current was decreased to 0.2 $\mathrm{mA}$ observing the muscle contraction response pattern and, with the help of a Hamilton syringe, $50 \mu \mathrm{L}$ lidocaine (Groups I and II) or tramadol/lidocaine (Groups III and IV) were administered by the previously filled needle lateral extension (15 $\mu L)$. After drug administration the extension was washed with $15 \mu \mathrm{L}$ saline.

Motor block evaluation: time for progressive and total motor block regression was recorded and was characterized by observing animals' gait. Values from zero to 3 were attributed to the following criteria: $0=$ total absence of motor block, unchanged gait; 1 = minimum motor block, normal gait however with paw inversion; 2 = moderate motor block, animals traction the paw using thigh muscles, but paw is flaccid and does not support the plantar aspect on surface; $3=$ total motor block, totally flaccid paw.

Experimental design: animals were distributed in four different study groups. The first group (GI) was submitted to sci- atic nerve block with $2 \%$ lidocaine. The second group (GII) received $0.5 \%$ lidocaine. The third group (GIII) received $2 \%$ lidocaine and $1.25 \mathrm{mg}$ tramadol. The fourth group (GIV) received $0.5 \%$ lidocaine associated to $1.25 \mathrm{mg}$ tramadol. Motor block duration and intensity were observed in the four groups. Tramadol concentration was based on a previous study, which has observed the presence of minimum motor block with $2.5 \%$ tramadol concentration without changing flinching ability.

\section{Statistical analysis}

Data are shown as mean \pm MSE (mean standard error) of 5 animals from each group and were analyzed by ANOVA followed by Tukey test for multiple comparisons with the help of GraphPad Prism version 5.0 software, considering significant $\mathrm{p}<0.05$.

This study was approved by the Research Ethics Committee, School of Medicine, University of São Paulo (protocol 051/2002).

\section{RESULTS}

Sciatic nerve was blocked according to the technique described by Sousa et al. ${ }^{5}$, in compliance with IASP ethical recommendations for the study of conscious animals ${ }^{6}$. Emergence time of rats after isoflurane withdrawal was similar for the four groups $(2.13 \pm 0.18,2.33 \pm 0.25,2.58 \pm 0.22,2.47$ \pm 0.31 minutes for $2 \%$ lidocaine, $0.5 \%$ lidocaine, $2 \%$ lidocaine/tramadol and $0.5 \%$ lidocaine/tramadol) respectively GI, GII, GIII, GIV.

In all groups, animals had total motor block at emergence (degree 3).

Total motor block regression time of $2 \%$ lidocaine $(41 \pm$ 1.71 minutes) was significantly better than of $0.5 \%$ lidocaine $(25.26 \pm 0.83$ minutes $)(p<0.05)$. Tramadol associated to lidocaine has prolonged total motor block regression time of $0.5 \%$ lidocaine $(36.16 \pm 1.19$ versus $25.26 \pm 0.83$ minutes, of tramadol / $0.5 \%$ lidocaine and of $0.5 \%$ lidocaine, respectively) $(\mathrm{p}<0.05)$, but did not significantly change $2 \%$ lidocaine total motor block regression time $(46.06 \pm 2.88$ versus $41 \pm$ 1.71 minutes, for tramadol / $2 \%$ lidocaine and $2 \%$ lidocaine, respectively) ( $\mathrm{p}>0.05)$ (Graph 1$)$.

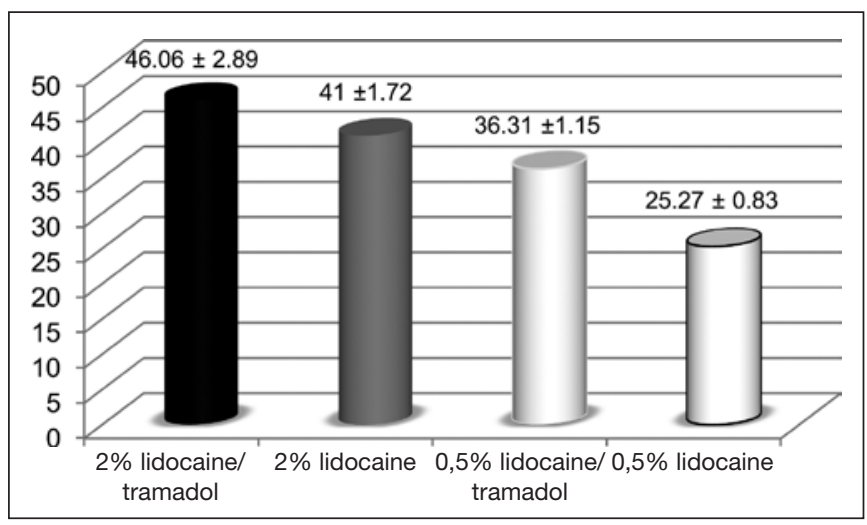

Graph 1 - Lidocaine-induced motor block regression time (in minutes) in sciatic nerve of rats. 
Table 1 - Motor block duration.

\begin{tabular}{lccccc}
\hline & Emergence Time & Blockade Level 3 & Blockade Level 2 & Blockade Level 1 & Blockade Level 0 \\
\hline 2\% Lidocaine & $128.4 \pm 11.2$ & $284 \pm 12.78$ & $555 \pm 36.84$ & $1147.6 \pm 50.18$ & $2460 \pm 106.76$ \\
$0.5 \%$ Lidocaine & $140.2 \pm 15.47$ & $232 \pm 6.44$ & $394.4 \pm 16.2$ & $693.8 \pm 54.3$ & $1516.2 \pm 50$ \\
$2 \%$ Lidocaine + tramadol & $155 \pm 13.22$ & $411.2 \pm 21.97^{*}$ & $706.8 \pm 30.1$ & $1370 \pm 48.6$ & $2764 \pm 173$ \\
$0.5 \%$ Lidocaine + tramadol & $148.4 \pm 19$ & $303 \pm 10.4^{*}$ & $816 \pm 16$ & $1509 \pm 67$ & $2170 \pm 69$ \\
\hline
\end{tabular}

Tramadol associated to $2 \%$ lidocaine has increased intense motor block duration as compared to $2 \%$ lidocaine alone; $p<0.05$.

The addition of $1.25 \mathrm{mg}$ tramadol to $0.5 \%$ lidocaine solution has significantly increased the duration of the effect of $0.5 \%$ lidocaine alone $(\mathrm{p}<0.05)$. ANOVA followed by Tukey test. Motor block regression time from degree 3 to degree 2, however, was longer in the group receiving $2 \%$ lidocaine associated to tramadol $(6.85 \pm 0.36$ minutes $)$ as compared to $2 \%$ lidocaine alone $(4.73 \pm 0.21$ minutes $)(p<0.05)$ (Table 1$)$.

\section{DISCUSSION}

The administration of anesthetic solutions close to peripheral nerves or neural complexes induces longer anesthesia as compared to neuraxial blocks, depending on physical agent characteristics and the presence or not of vasoconstrictors ${ }^{7}$. Combinations of local anesthetics and adjuvants, such as epinephrine ${ }^{8}$, ketamine ${ }^{9}$, neostigmine ${ }^{10}$, clonidine ${ }^{11}$ opioids and dexmedetomidine ${ }^{12}$ aim at prolonging analgesia time, allowing the use of local anesthetics in low concentrations and subsequent decrease of drug noxious effects.

Our study has evaluated duration and total regression of motor block induced by different lidocaine concentrations in mixed peripheral nerve, made up of sensory and motor fibers of different diameters with different sensitivities to local anesthetics. According to our results, it is clear that tramadol added to lidocaine has prolonged motor block duration.

Previous studies have reported significant better quality of analgesia with tramadol associated to ropivacain $e^{13}$ and intraarticular bupivacaine ${ }^{14}$, as well as with lidocaine for brachial plexus block in orthopedic surgeries in humans ${ }^{15}$; however, authors have not mentioned motor block duration. Our study has shown that motor block induced with $0.5 \%$ lidocaine, but not with $2 \%$ lidocaine, was prolonged by the addition of tramadol.

Such effect might have been caused by tramadol action on perineural adrenergic fibers, prolonging lidocaine action on sciatic nerve fibers ${ }^{16}$. However, the most likely possibility for such effect is the action of tramadol on the kinetics of sodium channel, where it decreases neural excitability ${ }^{17}$, the mechanism of which is possibly different from lidocaine ${ }^{16}$ and not totally clear. In addition, in vivo, tramadol blocks neural somatosensory potentials conduction ${ }^{17}$ and has local anesthetic effect as effective as $2 \%$ prilocaine $^{18}$. When directly applied on the sciatic nerve, it dose-dependently blocks neural conduction $^{3}$ with lower potency as compared to lidocaine ${ }^{16}$, being critical the proximity of neural sheaths for the synergistic effect ${ }^{19}$.

We have not found significant increase in total duration of $2 \%$ lidocaine effect in this model. However, animals receiving tramadol associated to $2 \%$ lidocaine had deep neural block (degree 3) for a longer time as compared to those submitted to $2 \%$ lidocaine alone, which could be understood as indirect measurement of motor block intensity. One hypothesis for this phenomenon might have been the participation of tramadol in the early conduction blockade stage, where blockade duration is limited by drug potency.

Clinically, the association of tramadol to loco-regional anesthesia might decrease surgical stress and improve postoperative recovery in humans, due to the physiological advantages of such techniques and to the possibility of early hospital discharge ${ }^{20}$. However, there have been limitations to the technique and the models of our study because it was impossible to measure blockade onset time.

\section{CONCLUSION}

Current results allow concluding that tramadol may be used as adjuvant for lidocaine, prolonging motor block recovery time in rats, possibly by mechanisms similar to local anesthetics.

\section{REFERENCES}

1. Bamigbade TA, Langford RM. Tramadol hydrochloride: an overview of current use Hosp Med. 1998 May;59(5):373-6.

2. Raffa RB, Friderichs E, Reinmann W, et al. Opioid and nonopioid components independently contribute to the mechanism of action of tramadol, an 'atypical' opioid analgesic. J Pharmacol Exp Ther. 1992;260(1):275-85.

3. Katsuki R, Fujita T, Koga A, et al. Tramadol, but not its major metabolite (mono-O-desmethyl tramadol) depresses compound action potentials in frog sciatic nerves. $\mathrm{Br}$ J Pharmacol. 2006;149(3):319-27.

4. Tsai YC, Chang PJ, Jou IM. Direct Tramadol application on sciatic nerve inhibits spinal somatosensory evoked potentials in rats. Anesth Analg. 2001;92(6):1547-51.

5. Sousa AM, Ashmawi HA, Costa LS, et al. Percutaneous sciatic nerve block with tramadol induces analgesia and motor blockade in two animal pain models. $\mathrm{Br} \mathrm{J}$ Med Biol Res. 2012;45(2):147-52.

6. Zimmermann M. Ethical guidelines for investigations of experimental pain in conscious animals. Pain. 1983;16(2):109-10.

7. Katz S, Drum M, Reader A. et al. A Prospective, randomized, double-blind comparison of $2 \%$ lidocaine with 1:100,000 epinephrine, $4 \%$ prilocaine with 1:200,000 epinephrine, and 4\% prilocaine for maxillary infiltrations. Anesth Prog. 2010;57(2):45-51.

8. Connelly NR, Freiman JP, Lucas T, et al. Addition of epinephrine to epidural bupivacaine infusions following initiation of labor analgesia with epidural fentanyl. J Clin Anesth, 2011;23(4):265-9.

9. Schnabel A, Poepping DM, Kranke P, et al. Efficacy and adverse effects of ketamine as an additive for paediatric caudal anaesthesia: a quantitative systematic review of randomized controlled trials. Br J Anaesth. 2001;107(4):601-11.

10. Taheri R, Shayeghi S, Razavi SS, et al. Efficacy of bupivacaine-neostigmine and bupivacaine-tramadol in caudal block in pediatric inguinal herniorrhaphy. Paediatr Anaesth. 2010;20(9):866-72.

11. Bazin M, Bonnin M, Storme B, et al. Addition of clonidine to a continuous patient-controlled epidural infusion of low-concentration levobupivacaine plus sufentanil in primiparous women during labour. Anaesthesia. 2001;66(9):769-79.

12. Brummett CM, Padda AK, Amodeo FS et al. Perineural dexmedetomidine added to ropivacaine causes a dose-dependent increase in the duration of thermal antinociception in sciatic nerve block in rat. Anesthesiology. 2009;111(5):1111-9. 
13. Günes Y, Seçen M, Özcengiz D, et al. Comparison of caudal ropivacaine, ropivacaine plus ketamine and ropivacaine plus tramadol administration for postoperative analgesia in children. Paediatr Anaesth. 2004;14(7):557-63.

14. Zeidan A, Kassem R, Nahleh N, et al. Intraarticular tramadol-bupivacaine combination prolongs the duration of postoperative analgesia after outpatient arthroscopic knee surgery. Anesth Analg. 2008;107(1):292-9.

15. Kaabachi O, Ouezini R, Koubaa W, et al. Tramadol as an adjuvant to lidocaine for axillary brachial plexus block. Anesth Analg. 2009;108(1):367-70.

16. Mert T, Gunes Y, Ozcengiz D, et al. Comparative effects of lidocaine and tramadol on injured peripheral nerves. Eur J Pharmacol. 2006;543(1-3):54-62.
17. Dalkilic N, Tuncer $S$, Bariskaner $H$, et al. Effect or tramadol on the rat nerve conduction: a numerical analysis and conduction velocity distribution study. Yakugaku Zasshi. 2009;129(4):485-93.

18. Altunkaya H, Ozer Y, Kargi E, et al. The postoperative analgesic effect of tramadol when used as subcutaneous local anesthetic. Anesth Analg. 2004;99(5):1461-4.

19. Kumar M, Batra YK, Panda NB, et al. Tramadol added to bupivacaine does not prolong analgesia of continuous psoas compartment block. Pain Pract. 2009;9(1):43-50.

20. Carli F, Kehlet H, Baldini G, et al. Evidence basis for regional anesthesia in multidisciplinary fast-track surgical care pathways. Reg Anesth Pain Med. 2011;36(1):63-72. 


\section{Evaluation of the addition of tramadol on lidocaine-induced motor block regression time. Experimental study in rats}

Avaliação da adição do tramadol sobre o tempo de regressão do bloqueio motor induzido pela lidocaína. Estudo experimental em ratos

Angela Maria Sousa, Martim M Cutait, Hazem Adel Ashmawi

Rev Dor. São Paulo, 2013;14(2):130-3

In the above mentioned article, graph 1 was published with error.

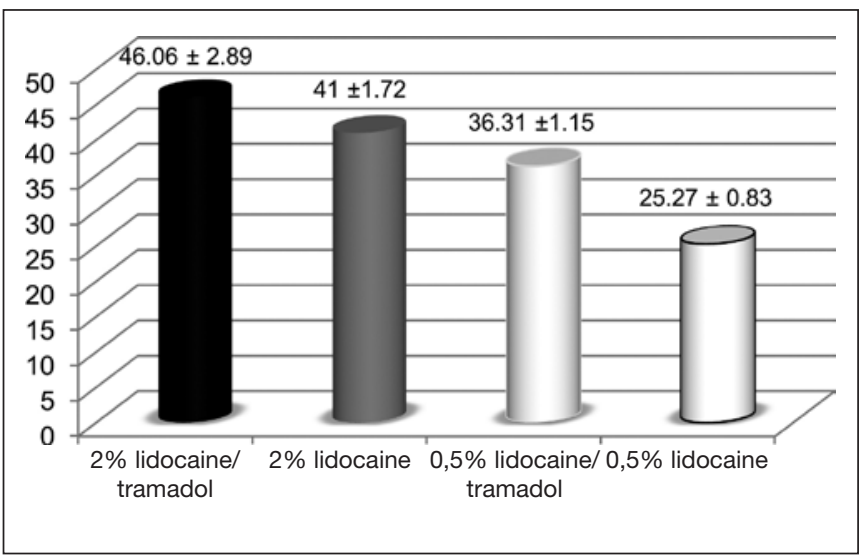

Graph 1 - Lidocaine-induced motor block regression time (in minutes) in sciatic nerve of rats.

Best regards,

Angela Maria Sousa 